\title{
METABOLIC SYNDROME, OVERWEIGHT, HYPERLEPTINEMIA IN CHILDREN AND ADULTS
}

DOI:10.36740/WLek202102126

\author{
Olesia M. Bochar, Helena Y. Sklyarova, Khristina Y. Abrahamovych, Natalia M. Hromnats'ka, Volodymyr T. Bochar, \\ Eugen Y. Sklyarov \\ DANYLO HALYTSKY LVIV NATIONAL MEDICAL UNIVERSITY, LVIV, UKRAINE
}

\begin{abstract}
The aim: To evaluate anthropometric, hemodynamic parameters, as well as changes in blood and leptin lipid spectrum in children and adults with overweight and obesity. Materials and methods: We examined 68 overweight children and 90 patients with obesity in combination with stage 2 , grade 2 AH who were electively inpatient. The control group consisted of practically healthy individuals -20 adults and 55 children.

Results: Obesity in childhood isaccompanied by the development of dyslipidemia, hypercholesterolemia, hyperleptinemia and hypertension, and in adulthood may be an additional risk factor for cardiovascular disease, in particular AH. According to the study, total leptin level in overweight children was significantly higher compared to the control group ( $p<0.01$ ). The concentration of leptin in patients with hypertension in combination with obesity was 3 times higher compared to the control group ( $<<0.01$ ) Conclusions: Thus, obesity or overweight, accompanied by hyperleptinemia and an increase in the proatherogenic fractions of the blood lipid spectrum, is an important problem that needs to be addressed in childhood to prevent cardiovascular disease in adulthood.
\end{abstract}

KEY WORDS: arterial hypertension, obesity, overweight, leptin

Wiad Lek. 2021;74(2):313-316

\section{INTRODUCTION}

At present, obesity and overweight have become one of the most serious public health problems, due to the significant increase of their prevalence among population of different age groups in all countries [1, 2, 3, 4]. According to prognosis, by 2030, an increase in excess body weight is expected in adults up to $86.3 \%$ and obesity up to $51.1 \%$ [5].

In the age-related population, overweight occurs in $20 \%$ of children and teenagers. It is estimated that almost every 5 th European child has abnormal body weight $[6,7]$. The highest incidence of overweight in teenagers is $28.9 \%$ in boys and $16.4 \%$ in girls in Greece. In Italy, almost $36 \%$ of children aged 9 are overweight or obese, and in Spain, 26.6\% of children aged 9-13 are diagnosed with overweight, almost $4 \%$ are obese $[6,7]$. In overweight and obese children, hyperleptinemia is found in $80 \%$ of cases, in adults with metabolic syndrome (MS) hyperleptinemia is found in 72\% [8]. In adults, hyperleptinemia is an independent factor for the development of coronary heart disease and arterial hypertension.

The manifestation of obesity is MS, which contributes to the occurrence of atherosclerosis, type 2 diabetes, which leads to increased mortality in the population $[9,10]$. One of the components of MS is abdominal obesity. An important role in the development and progression of metabolic disorders is played by adipose tissue, which synthesizes a large number of adipocytokines, among which hyperleptinemia plays an important role in the occurrence of coronary heart disease, hypertension, diabetes and stroke. $[9,11]$.
High levels of leptin in the blood plasma are also accompanied by activation of the sympathetic nervous system, endothelial dysfunction, oxidative stress, proinflammatory and prothrombotic disorders $[8,10]$.

Despite the considerable body of research on the pathogenesis of MS, this issue needs further study in terms of search of effective prevention of obesity-related diseases.

\section{THE AIM}

The aim of the study was to evaluate anthropometric, hemodynamic parameters, as well as changes in blood and leptin lipid spectrum in children and adults with overweight and obesity.

\section{MATERIALS AND METHODS}

We examined 68 overweight children and 90 patients with obesity in combination with stage 2 , grade $2 \mathrm{AH}$ who were electively inpatient. The control group consisted of practically healthy individuals -20 adults and 55 children.

Among the surveyed children, 49 (72\%) girls were overweight, boys - $19(28 \%)$, average age was $13.12 \pm 0.38$. In the group of patients with combined pathology (AH with obesity), there were $49(54.4 \%)$ men, women - 41 (45.6\%), the average age was $57.49 \pm 1.07$.

All patients underwent anthropometric, general clinical, laboratory (blood lipid spectrum), instrumental - electro- 
Table I. Anthropometric and hemodynamic parameters in children and adults with overweight and obesity

\begin{tabular}{ccccc}
\hline Indicators & $\begin{array}{c}\text { Control group } \\
(\mathbf{n = 5 5 )}\end{array}$ & $\begin{array}{c}\mathbf{6 8} \text { overweight } \\
\text { children }\end{array}$ & $\begin{array}{c}\text { Control group } \\
(\mathbf{n = 2 0})\end{array}$ & $\begin{array}{c}\mathbf{9 0} \text { patients with } \\
\text { hypertension and obesity }\end{array}$ \\
\hline $\mathrm{BMI}, \mathrm{kg} / \mathrm{m}^{2}$ & $19,10 \pm 0,31$ & $28,82 \pm 0,49^{* *}$ & $23,98 \pm 0,16$ & $32,24 \pm 0,52^{* *}$ \\
\hline $\mathrm{WV}, \mathrm{cm}$ & $68,00 \pm 1,00$ & $96,60 \pm 0,81^{* *}$ & $73,80 \pm 0,92$ & $95,87 \pm 1,33^{* *}$ \\
\hline $\mathrm{TV}, \mathrm{cm}$ & $85,00 \pm 1,29$ & $106,01 \pm 1,73^{* *}$ & $91,38 \pm 0,34$ & $91,92 \pm 0,55$ \\
\hline Index WV/TV & $0,78 \pm 0,01^{* *}$ & $0,86, \pm 0,02$ & $0,80 \pm 0,01$ & $0,96 \pm 0,01^{*}$ \\
\hline $\mathrm{SBP}, \mathrm{mm} \mathrm{Hg}$, & $110,00 \pm 1,23$ & $133,11 \pm 2,05^{* *}$ & $132,00 \pm 0,82$ & $168,20 \pm 2,28^{*}$ \\
\hline $\mathrm{DBP}, \mathrm{mm} \mathrm{Hg}$, & $70,01 \pm 1,63$ & $80,49 \pm 1,50^{* *}$ & $76,50 \pm 1,07$ & $107,20 \pm 0,66^{*}$ \\
\hline
\end{tabular}

Note: ${ }^{* *} p<0,05$ compared to control group, ${ }^{*} p<0,01$ compared to control group

Table II. Indicators of lipid spectrum of blood and leptin in children and adults with overweight and obesity

\begin{tabular}{|c|c|c|c|c|}
\hline Indicators & $\begin{array}{c}\text { Control group } \\
(n=55)\end{array}$ & $\begin{array}{l}68 \text { overweight } \\
\text { children }\end{array}$ & $\begin{array}{c}\text { Control group } \\
(n=20)\end{array}$ & $\begin{array}{c}90 \text { patients with hypertension } \\
\text { and obesity }\end{array}$ \\
\hline $\mathrm{TC}, \mathrm{Mmol} / \mathrm{l}$ & $3,60 \pm 0,15$ & $4,54 \pm 0,14^{*}$ & $4,32 \pm 0,09$ & $6,05 \pm 0,13^{*}$ \\
\hline $\mathrm{TG}, \mathrm{Mmol} / \mathrm{I}$ & $1,06 \pm 0,06$ & $1,35 \pm 0,08^{*}$ & $1,47 \pm 0,06$ & $2,13 \pm 0,13^{*}$ \\
\hline LDL, Mmol/I & $1,78 \pm 0,09$ & $2,44 \pm 0,11^{*}$ & $2,62 \pm 0,09$ & $3,63 \pm 0,05^{*}$ \\
\hline $\mathrm{HDL}, \mathrm{Mmol} / \mathrm{l}$ & $1,31 \pm 0,07$ & $1,42 \pm 0,06$ & $1,25 \pm 0,04$ & $1,14 \pm 0,05^{*}$ \\
\hline Leptin, ng/ml & $7,88 \pm 2,06$ & $27,65 \pm 3,67^{* *}$ & $10,54 \pm 1,02$ & $31,72 \pm 2,59 * *$ \\
\hline
\end{tabular}

Note: ${ }^{* *} p<0,05$ compared to control group, ${ }^{*} p<0,01$ compared to control group

cardiography, echocardiography, ultrasonography (USG) and enzyme immunoassay (leptin).

The diagnosis of $\mathrm{AH}$ was established using standards of diagnosis and treatment in accordance with the recommendations of the Ukrainian Association of Cardiologists, the European Society of Hypertension and the European Society of Cardiologists (ESH / ESC). Plan of examination and treatment tactics was guided by the order of the Ministry of Health of Ukraine No. 384 of 24.05.2012, «On approval and implementation of medical and technological documents on standardization of medical care for arterial hypertension».

Patients were measured for height and weight, body mass index was calculated according to conventional formulas.

Office blood pressure was measured according to standard of examination. Measured systolic blood pressure (SBP) and diastolic blood pressure (DBP)/ Heart rate was determined after the second pressure measurement.

All persons underwent USG of the internal organs, upon which special attention was paid to the increase in the size of the liver, the density of its parenchyma, diffuse uniform increase in echogenicity, the appearance of the effect of distal shading and the diameter of the portal vein.

All enzyme immunoassay methods were performed using a «Statfax 303 plus» analyzer (AwarenessTechnology, USA).

Leptin content was determined using the DRG «Leptin ELISA» kit (Germany), using on the sandwich principle.
Research was conducted according to the method of enzyme immunoassay.

The results were statistically processed using the Student's $\mathrm{t}$ test, Pearson correlation analysis using the «MS Excel software».

\section{RESULTS AND DISCUSSION}

The study enrolled inpatient patients, who underwent treatment with AH stage II, grade 2 moderate, high and very high risk in combination with obesity and children undergoing outpatient care by a family physician due to overweight.

Overweight was diagnosed in 25 (36.76\%) children, respectively.

Obesity of the 1st degree was diagnosed in 61 (67.78\%) patients, 2nd - in $22(24.44 \%)$, 3rd degree - in $7(7.78 \%)$. Obesity was observed in 87 (96.67\%) patients. Significant increase in total body weight, BMI, thigh volume (TV), and $\mathrm{TV} /$ waist volume (WV) index was found in overweight children and in the group of patients with combined pathology compared with the control group $(\mathrm{p}<0.05)$. There was no significant difference in $\mathrm{WV}$ in the group with combined pathology (Table 1).

The mean level of SBP and DBP was significantly higher in overweight children $(\mathrm{p}<0.05)$ and in patients with combined pathology $(\mathrm{p}<0.01)$ compared with controls (Table 1). 
According to the results of USG, in children with overweight there was a slight increase in the size of the liver $18(26.47 \%)$ and in $34(50.0 \%)$ children we revealed the heterogeneity of its structure and increased echogenicity of the parenchyma.

An ultrasonographic increase of liver size was found in 90 (81.8\%) subjects with AH with obesity, such changes were absent in control subjects. Hyperechogenicity of the liver parenchyma was observed in $89(80.9 \%)$ of the examined persons, heterogeneity of the liver structure was diagnosed in $83(75.4 \%)$ persons.

The study of the lipid spectrum of the blood in the majority of patients indicates on significant increase in the levels of proatherogenic fractions, unlike the control group. Dyslipidemic changes were found in 59 (87.1\%) overweight children and 86 (95.56\%) patients with AH combined with obesity. In particular, an increase in total cholesterol (TC) levels was observed in $86(95.56 \%)$ patients, low density lipoprotein (LDL) in 60 (66.67\%), triglycerides (TG) - in 47 (52.22\%). The level of high density lipoprotein (HDL) was maintained within the normal range in 45 patients (50.0\%) (Table 2).

According to the study, total leptin level in overweight children was significantly higher compared to the control group $(p<0.01)$. The concentration of leptin in patients with hypertension in combination with obesity was 3 times higher compared to the control group $(\mathrm{p}<0.01)$ (Table 2). An increase in leptin levels above the reference values was detected in $80 \%$ of the surveyed individuals, indicating on impaired metabolic processes in combined pathology.

It is known that the use of statins, in particular atorvastatin for the correction of blood lipid spectrum helps to reduce leptin levels in adults $[12,13]$. However, the prescription of statins in children is impractical because of many side factors. As a result, the problem of preventing obesity in children requires lifestyle adjustments.

Obesity in childhood is accompanied by the development of dyslipidemia, hypercholesterolemia, hyperleptinemia and hypertension, and in adulthood may be an additional risk factor for cardiovascular disease, in particular $\mathrm{AH}[14,15]$.

\section{CONCLUSIONS}

Thus, obesity or overweight, accompanied by hyperleptinemia and an increase in the proatherogenic fractions of the blood lipid spectrum, is an important problem that needs to be addressed in childhood to prevent cardiovascular disease in adulthood.

\section{REFERENCES}

1. Dang Dang N.M., El_Serag Hashem B. The Epidemiology of Obesity. Gastroenterology Clinics of North America. 2010;39 (1):1-7.

2. Singh G.K., Siahpush M., Hiatt R.A., Timsina L.R. Dramatic Increases in Obesity and Overweight Prevalence and Body Mass Index Among Ethnic_Immigrant and Social Class Groups in the United States, 19762008. Journal of Community Health. 2010;36 (1):94-110.
3. Gahagan Gahagan S., Kliegman R.M., Stanton B.F. et al. Overweight and obesity. Nelson Textbook of Pediatrics. Elsevier. 2016.

4. Pego-Fernandes P.M., Bibas B.J., Deboni M. P.-F. Obesity: the greatest epidemic of the 21st century? Sao Paulo Medical Journal. 2011;129(5):283-284.

5. Will Wang Y., Beydoun M.A., Liang L. et al. All American's become overweight or obese? Estimating the progression and cost of the us obesity epidemic. Obesity. 2008;16(10):2323-2330.

6. WHO Obesity : preventing and managing the global epidemic : report of a WHO consultation. (WHO technical report series WHO Consultation on Obesity. Geneva, Switzerland.1999.

7. Bammann K., Gwozdz W., Lanfer A. et al. Socioeconomic factors and childhood overweight in Europe: results from the multi-centre IDEFICS study. Pediatric Obesity. 2013;8(1):1-12.

8. Radchenko 0.M., Bek N.S., Potapov V.I. Leptynemiya ta pokaznyky variabelnosti rytmu sercya i prognoz u hvoryh na hipertonichnu hvorobu z ozhyrinnyam [Leptinemia, parameters of heart rate variability, and prognosis in patients with essential arterial hypertension with obesity] Bukovynskyj medychnyj visnyk. 2014;4(72):119-122. (in Ukrainian).

9. Friedman J.M. Leptin and the Regulation of Body Weight. Journal of Medical Sciences. 2010;3:3.

10. Owecki M., Nikisch E., Miczke A. et al. Leptin, soluble leptin receptors, free leptin index, and their relationship with insulin resistance and BMI: high normal BMl is the threshold for serum leptin increase in humans. Hormone and Metabolic Research. 2010;42(8):585-9.

11. Sun Q., van Dam R.M., Meigs J.B. et al. Leptin and soluble leptin receptor levels in plasma and risk of type 2 diabetes in U.S. women: a prospective study. Diabetes. 2010;59:611-618.

12. Sklyarov E.Y., Bochar 0.M., Lapovets L.Y. Dynamika pokaznykiv leptynu, adyponektynu ta interlejkinu-6 u pry pryznachenni sartaniv ta statyniv u paciyentiv $z$ arterialnoyu gipertenziyeyu poyednanoyu z ozhyrinnyam ta nealkogolnym steatogepatytom [Dynamics of indicators of leptin, adiponectin and interleukin-6 in the appointment sartans, statins and ursodeoxycholic acid in patients with hypertension combined with obesity and nonalcoholic steatohepatitis]. Zdobutky klinichnoyi i eksperymentalnoyi medycyny. 2017;3(31):137-142. (in Ukrainian).

13. Singh P., Zhang Y., Sharma P. et al. Statins decrease leptin expression in human white adipocytes. Physiological Reviews. 2018;6(2).

14. Kumar S., Kelly A.S. Review of Childhood Obesity: From Epidemiology, Etiology, and Comorbidities to Clinical Assessment and Treatment. Mayo Clin Proc. 2017;92(2):251-265.

15. Sklyarov E., Bochar 0., Bochar V. Leptin and interleukin-6 level in patients with hypertension and obesity combined with non-alcoholic steatohepatitis during treatment with sartans and statins. Current Issues in Pharmacy and Medical Sciences. 2017;30(2):57-60.

\section{ORCID and contributionship:}

Olesia M. Bochar: 0000-0001-5000-9415 B,D

Helena Y. Sklyarova: 0000-0003-3667-6304 ${ }^{B}$

Khristina Y.Abrahamovych: 0000-0002-0557-0227 ${ }^{E}$

Natalia M. Hromnats'ka: 0000-0002-9872-9451 ${ }^{\mathrm{A}}$

Volodymyr T. Bochar: 0000-0002-5100-8657 ${ }^{\mathrm{C}}$

Eugen Y. Sklyarov: 0000-0001-9037-0969 ${ }^{A, F}$

\section{Conflict of interest:}

The Authors declare no conflict of interest. 


\section{CORRESPONDING AUTHOR}

Volodymyr T. Bochar

Danylo Halytsky Lviv National Medical University,

9 Mykolaichuka st., 79059, Lviv, Ukraine

tel: +380679773668

email: bovotar@ukr.net

Received: 06.04 .2020

Accepted: 19.11 .2020

A - Work concept and design, B - Data collection and analysis, C - Responsibility for statistical analysis,

D-Writing the article, $\mathbf{E}$-Critical review, $\mathbf{F}$ - Final approval of the article 